\title{
Design and Economic Evaluation of a Solar Household Electrification System
}

\author{
M. Mujahid Rafique** \\ (mujahidrafique89@gmail.com) \\ *TU Bergakademie Freiberg 09599, Germany \\ \$Corresponding Author; M. Mujahid Rafique
}

Received: 19.06.2018 Accepted:28.06.2018

\begin{abstract}
In this paper, a simplified design and analysis approach has been used for assessment of a solar PV system for domestic household electrification in Pakistan. The load requirement of a typical domestic building is estimated and based on the load requirements system components for an off grid PV power system are designed. The total load requirement of the facility under study is estimated to be $28.10 \mathrm{kWh} /$ day. The required peak power and area of PV modules designed using developed model to fulfill load demand requirements is found to be $5.77 \mathrm{~kW}$ and $41.03 \mathrm{~m}^{2}$, respectively. Furthermore, life cycle cost and unit electricity cost of the system is determined using developed model. The achieved rate of electricity from solar PV system for household electrification is estimated to be $7.44 \mathrm{PKR} / \mathrm{kWh}$ which is about 50 to $55 \%$ cheaper as compared to grid supplied conventional electricity. The developed model and obtained results will encourage and provide a guideline for policy makers and people in the Country to install off grid solar PV systems for household electrification.
\end{abstract}

Keywords - renewable energy; solar PV; electrification rate; life cycle cost; sustainable development; Pakistan.

\section{Introduction}

In this age of modernization, the consumption of electricity in Pakistan is rising continuously in the domestic sector. This is due to the fact that, innovation in electronics sector has led towards more electrical appliances used in the household. This behavior is little bit different for industrial sector in which due to high power outages the large manufacturing plants have established their own power generating units to produce electricity and has become Independent Power Producers (IPPs) under the Power Policy 2002 [1]. Some of the examples of such companies include Nishat, Gul Ahmed, Orient, etc. All independent power producers (IPPs) were depending upon thermal generation from furnace oil under the 1994 policy. As a result, the overall share of oil in power generation has increased. This in turn led to heavy reliance on fluctuating oil prices. The yearly development of electricity installed capacity by types of different fuels is illustrated in Fig. 1. The major installed additions were Guddu, Nandipur thermal power plants with installed capacity 747 and 425 MW, respectively.

Pakistan's demand for electricity outstrips the current generation capacity leading to a shortfall of 4,500 - 5,500 MW as it can be observed from Fig. 2 [2]. Electric crisis in the Country has turned out to be the most significant hurdle in the economic development which not only creates social disturbance but also affecting the real GDP growth rate. In a report issued by National Electric Power Regulatory Authority (NEPRA), it is estimated that the electricity crisis is accountable for 2 to $3 \%$ decline in the GDP of the Country on annual basis.

According to world Energy outlook report, about 51 million people in Pakistan lives without electricity. The urban areas of the Country have $90 \%$ electrification rate whereas for rural areas this rate drops to $60 \%$. Furthermore, World Bank survey found that 30 to $45 \%$ of households use kerosene as a primary or secondary source of lighting [3]. Apart from shortfall of electricity in the Country, the increasing use of fossil fuels is a threat to environment. The emission of greenhouse gases are increasing at a rapid rate as depicted in Fig. 3 [4]. These issues of energy security and environmental degradation require the nation to diversify its energy mix.

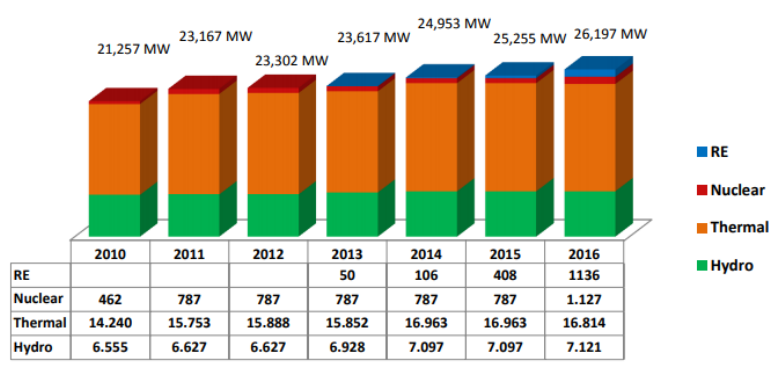

Fig. 1. Developments of electricity sector. 


\section{Source: CPPA, AEDB and NEPRA}

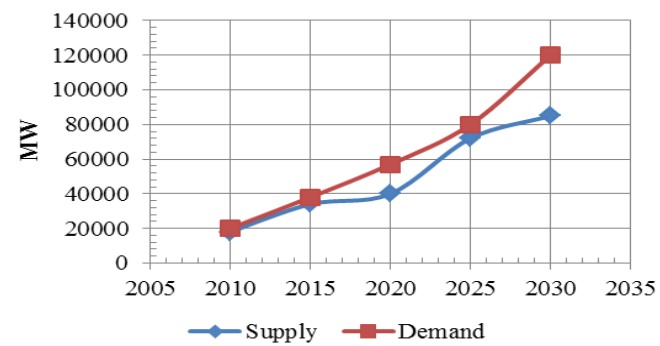

Fig. 2. Peak electricity demand vs. supply projections for Pakistan [2].

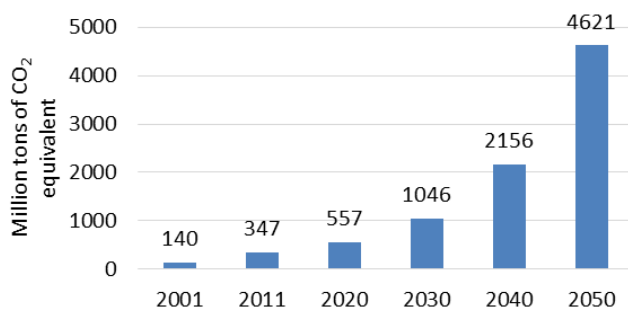

Fig. 3. Current and projected emissions of carbon dioxide for Pakistan [4].

Keeping all above mentioned aspects in mind, the major aim of this paper is to develop a design and sizing procedure for an off grid PV system. Using the developed procedure, feasibility of developing an off-grid PV system to supply the electrical energy for household electrification has been studied. The study focuses on the design aspects and unit electricity rate of a standalone solar PV electrification system to fulfill the required load demands of the facility. The detailed objectives and flow of the article are illustrated in Fig. 4. This study can be used as a benchmarking and guideline in order to design off-grid PV power systems for other facility with similar load demands which includes residential and other facilities.

\section{Materials and Method}

\subsection{Domestic household load requirements}

The typical household appliances used in Pakistan are lamps, fans television, refrigerator, air conditioner, washing machine, water pump, and electric iron. The operating schedules, ratings of appliances are illustrated in Table I.

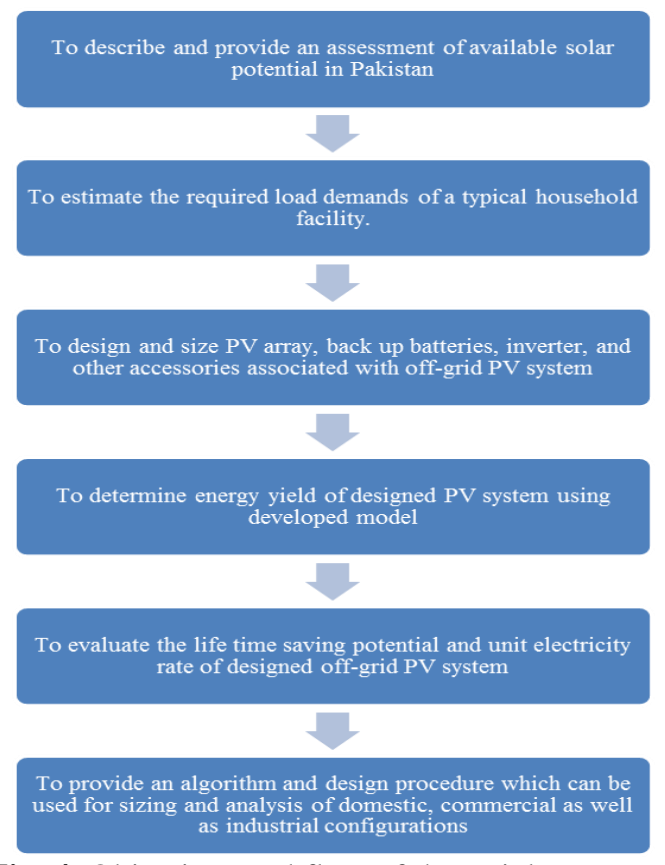

Fig. 4. Objectives and flow of the article.

Table I. Household load requirements in Pakistan.

\begin{tabular}{|c|c|c|c|c|}
\hline Appliances & $\begin{array}{c}\text { No. } \\
\text { of } \\
\text { Unit } \\
\text { s }\end{array}$ & $\begin{array}{c}\text { Operatin } \\
\text { g time } \\
\text { (hours) }\end{array}$ & $\begin{array}{c}\text { Wattag } \\
\text { e per } \\
\text { unit } \\
\text { (W) }\end{array}$ & $\begin{array}{c}\text { Total } \\
\text { daily load } \\
\text { (kWh/day } \\
\text { ) }\end{array}$ \\
\hline $\begin{array}{c}\text { Lighting } \\
\text { Lamp }\end{array}$ & 5 & 12 & 25 & 1.0 \\
\hline $\begin{array}{c}\text { Washing } \\
\text { Machine }\end{array}$ & 1 & 1 & 250 & 0.25 \\
\hline $\begin{array}{c}\text { Refrigerato } \\
\text { r }\end{array}$ & 1 & 13 & 180 & 2.3 \\
\hline $\begin{array}{c}\text { Water } \\
\text { Pump }\end{array}$ & 1 & 3 & 120 & 0.36 \\
\hline TV & 1 & 7 & 80 & 0.56 \\
\hline Fan & 3 & 8 & 60 & 1.26 \\
\hline Electric \\
Iron
\end{tabular}

\subsection{Solar resource assessment}

The geographic location of Pakistan, its topography, and climatic conditions are favorable for solar energy 
exploitation and utilization on national level. On an average, the Country receives about $1,900-2,200 \mathrm{kWh} / \mathrm{m}^{2}$ global solar radiation intensity annually. This puts Pakistan among the countries which are relatively rich in solar energy potential [5]. South East part of Punjab, South West province of Baluchistan, and North East part of Sindh are the sunniest parts of the Country. One of the richest provinces in terms of solar energy is Baluchistan which has about $20 \mathrm{MJ} / \mathrm{m}^{2}$ daily global insolation. These conditions are ideal for different solar energy applications such as solar PV and solar thermal. Average solar insolation data for the major cities of Pakistan is shown in Fig. 5 [6] whereas mean monthly climatic data for Pakistan is shown in Fig. 6 [7]. The average daily sunshine hours for Pakistan are 7. Furthermore, a high resolution annual solar resource map of Pakistan is shown in Fig. 7. It can be observed that, solar potential is high in all parts of the Country. The solar PV output potential is high throughout the Country.

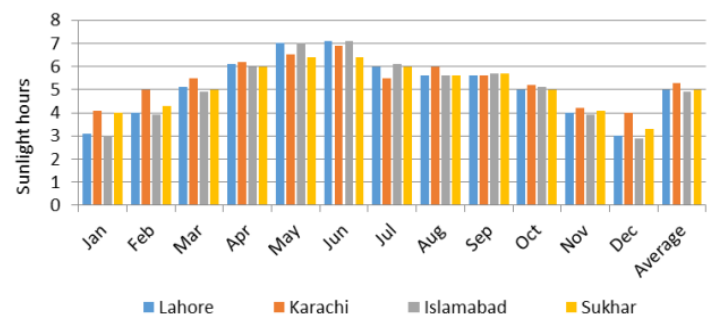

Fig. 5. Monthly average solar insolation for major cities.

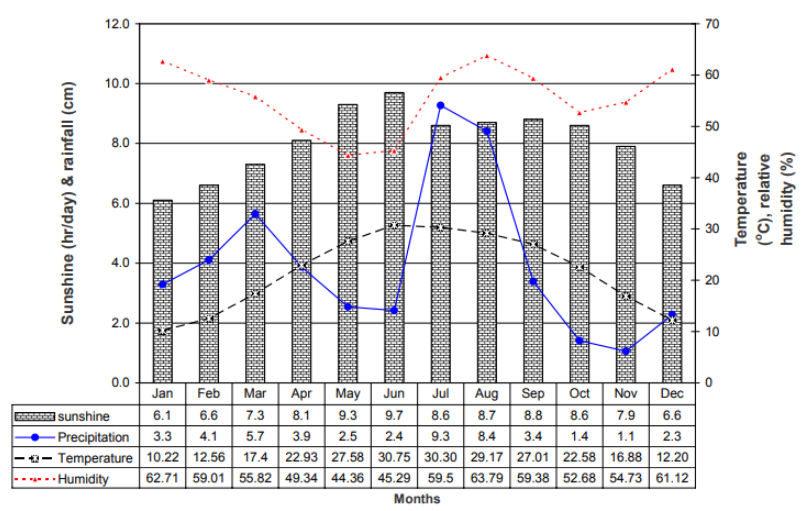

Fig. 6. Mean monthly climatic data for Pakistan [7].

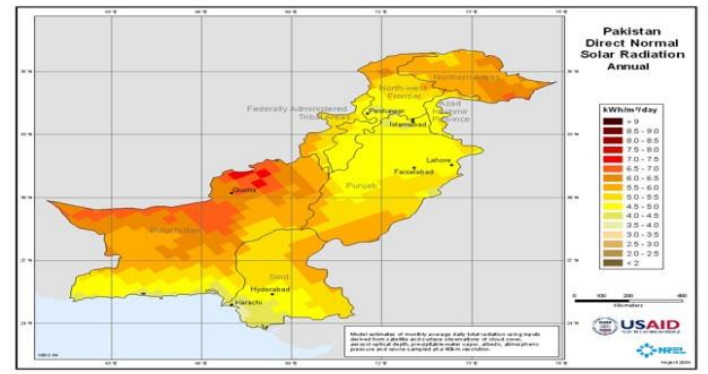

Fig. 7. Solar map of Pakistan.

\section{Design Results and Discussion}

The basic off-grid PV system consists of PV modules, inverter, back up storage system, and charge controller as shown in Fig. 8. The correct sizing and configuration of PV system for household electrification is very important for a predefined load demands. Depending upon the daily load requirements, the peak power of the PV module $\left(P_{P V}\right)$ can be obtained using following relationship [8]:

$$
P_{P V}=\frac{L_{\text {daily }}}{\eta_{\text {overall }} \times P S S H} \times S F
$$

The estimated value of daily load demand $\left(L_{\text {daily }}\right)$ is $28.10 \mathrm{kWh}$. The annual average daily peak sunshine hours $(P S S H)$ in Pakistan is 7 [7]. The values of overall system efficiency $\left(\eta_{\text {overall }}\right)$ and safety factor $(S F)$ for compensation of resistive and temperature losses are taken as $80 \%$ and 1.15 , respectively. The overall system efficiency accounts for connection losses, dust factor, inverter efficiency and charging efficiency.

Using the above mentioned values the required peak power of solar PV system is found to be $5.77 \mathrm{~kW}$. Based on load this required peak load demand of solar module, mono-crystalline PV module type mono-Si-STP180S-24 from Suntech with a module peak power of $180 \mathrm{~W}_{\mathrm{p}}$ is selected. The frame area of a module is $1.28 \mathrm{~m}^{2}$. The required number of modules required with the selected specification is 32 and installation of all these modules will require a total area of $41.03 \mathrm{~m}^{2}$. Based on the designed PV system a total capacity of $6.41 \mathrm{~kW}$ is required for an inverter with an efficiency of $90 \%$. The detailed specifications of the selected PV module are presented in Table II.

The intermittent nature of solar power requires the correct sizing of the backup storage system. The correct size of the battery is can be determined using equation (2). The ampere hour capacity $\left(C_{A h}\right)$ and watt hour capacity $\left(C_{W h}\right)$ of the battery block, with a maximum of 1 continuous days without sun can be determined using equation (2) and (3), respectively [8].

$$
\begin{gathered}
C_{A h}=\left(\frac{L_{\text {daily }}}{V_{B} \times \eta_{B} \times D O D}\right) \\
C_{W h}=C_{A h} \times V_{B}
\end{gathered}
$$

Where, values of battery bank voltage $\left(V_{B}\right)$ and efficiency $\left(\eta_{B}\right)$ are taken as $85 \%$ and $24 \mathrm{~V}$, respectively while permissible depth of discharge (DOD) for the battery is assumed to be 0.80 . Using these values a battery with a capacity of $1720 \mathrm{Ah} / 41.28 \mathrm{kWh}$ is required for continuous electrification of the facility under study. The size of the charge controller can be obtained by dividing the maximum capacity of PV array with battery bank design voltage [9]. The required size of the charge controller for this study is $240 \mathrm{~A}$. The designed values of all the components to fulfill required load demands are summarized in Table III. 
Furthermore, a sensitivity analysis has been performed and sizes of the system components are determined for different peak sunshine hours. The required size of PV module corresponding to peak sunshine hours of $5,5.5,6$, and 6.5 is found to be $8.08,7.34,6.73$, and $6.21 \mathrm{~kW}$, respectively as it can be observed from Fig. 9. Similarly, the required size of the inverter varies from 8.88 to 6.83 with the variations of peak sunshine hours from 5 to 6.5 as shown in Fig. 9. The variation of required size of charge controller with respect to different peak sunshine hours is presented in Fig. 10. The required size of the charge controller decreases from a value of 337 to $258 \mathrm{~A}$ with the increase of peak sunshine hours from 5 to 6.5 .

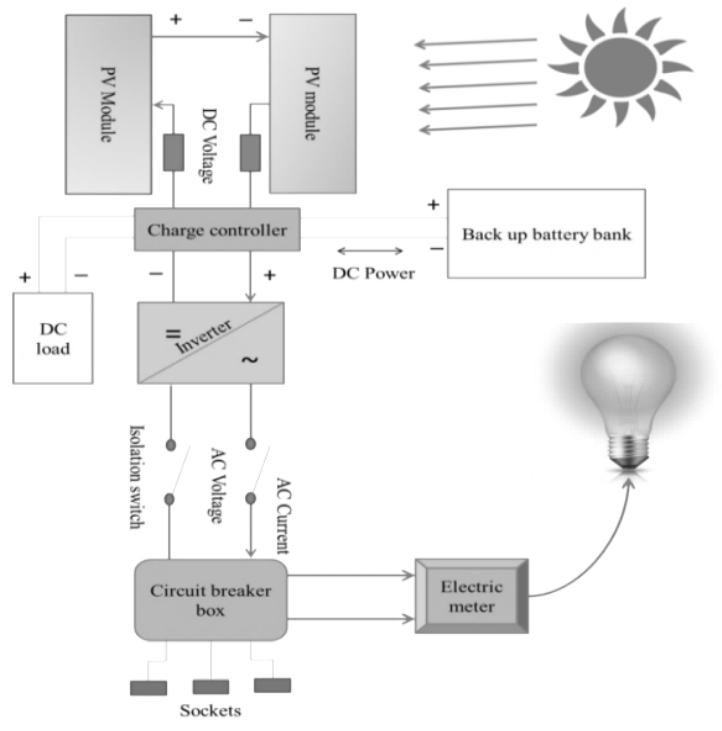

Fig. 8. Off-grid PV system.

Table II. PV module specifications.

\begin{tabular}{|l|c|c|}
\hline & Unit & Specification \\
\hline Type of module & - & mono-Si \\
\hline Peak capacity per module & $\mathrm{W}$ & 180 \\
\hline Manufacturer & - & Suntech \\
\hline Model & - & $\begin{array}{c}\text { mono-Si- } \\
\text { STP180S-24 }\end{array}$ \\
\hline Module efficiency & $\%$ & $14.1 \%$ \\
\hline $\begin{array}{l}\text { Nominal operating cell } \\
\text { temperature }\end{array}$ & ${ }^{\circ} \mathrm{C}$ & 45 \\
\hline $\begin{array}{l}\text { Temperature coefficient } \\
\%\end{array}$ & ${ }^{\circ} \mathrm{C}$ & $0.40 \%$ \\
\hline $\begin{array}{l}\text { Solar collector area per } \\
\text { module }\end{array}$ & $\mathrm{m}^{2}$ & 1.28 \\
\hline
\end{tabular}

Table III. Designed system components for an average value sunshine.

\begin{tabular}{|l|c|}
\hline Component & Capacity \\
\hline PV module & $5.77 \mathrm{~kW}$ \\
\hline Inverter & $6.41 \mathrm{~kW}$ \\
\hline Battery & $1720 \mathrm{Ah} / 41.28 \mathrm{kWh}$ \\
\hline $\begin{array}{l}\text { Charge } \\
\text { controller }\end{array}$ & $240 \mathrm{~A}$ \\
\hline
\end{tabular}

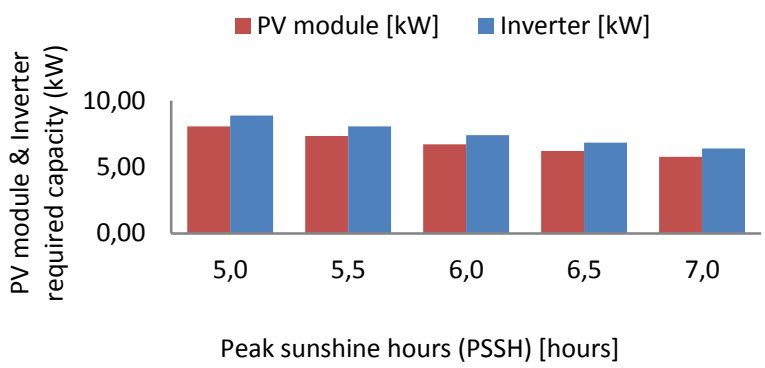

Fig. 9. Required size of PV module and inverter for different peak sunshine hours.

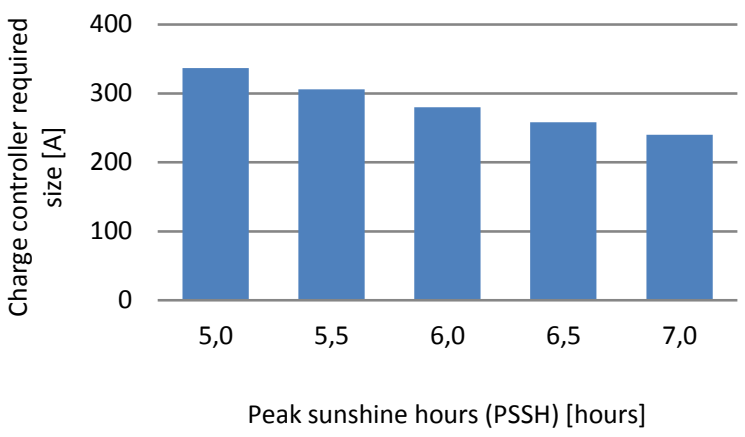

Fig. 10. Required size of charge controller for different peak sunshine hours.

The determination of life cycle cost and unit rate of electricity is an important aspect in order to assess the financial viability of the installed power system. The acquisition costs of an off grid PV system include costs of PV array, inverter, battery banks, and charge controller and are determined from the unit costs available in the Country. Whereas, as operating and installation costs are normally taken as the percentage of PV modules cost. The detailed procedure and description of relationships used for life cycle cost analysis are presented in Fig. 11. In Fig. 11 , the terms $C_{P V i}, C_{B i}, C_{I i}$, and $C_{c c i}$ represents unit cost of PV array, battery, inverter, and charge controller, reactively. The lifetime $(N)$ of the installed PV system is taken as 25 years except batteries for which 5 years of life cycle are considered. For the assessment of life cycle costs an inflation rate $(i)$ of $8 \%$ and a discount rate $(d)$ of $10 \%$ is considered depending upon the data for Pakistan. The 
other costs associated with solar PV system such as cabling etc. are counted as miscellaneous costs and are taken as $2 \%$ of initial cost of PV system.

The associated unit costs of system components based on market prices in Pakistan and other associated factors for financial analysis are presented in Table IV. The unit prices mentioned for all components are the average market available prices in Pakistan. Using above developed model and methodology for life cost analysis of the system, the costs associated with individual components of the system are calculated. The obtained results are illustrated in Table V. At the time of this study $1 €$ is equal to $130 \mathrm{PKR}$. The cost of above designed PV array, inverter, and charge controller is found to be 577,000 PKR, 128,200 PKR, and 12,020 PKR, respectively. The total cost of initial group of batteries and replacement set of batteries with above designed capacity is found to be $757,833 \mathrm{PKR}$. Finally, the total life cycle cost of the off-grid PV system is found to be 1,544,293 PKR. This cost also includes system installation, maintenance and miscellaneous costs. With a discount and inflation rate of $10 \%$ and $8 \%$, respectively, the annualized cost of the system over a lifetime of 25 years is estimated to be $76,332 \mathrm{PKR} /$ year. As, the total daily load demand of the residential building is $28.10 \mathrm{kWh}$, the calculated cost of electricity for one unit is $7.44 \mathrm{PKR} / \mathrm{kWh}(0.057 € / \mathrm{kWh})$.

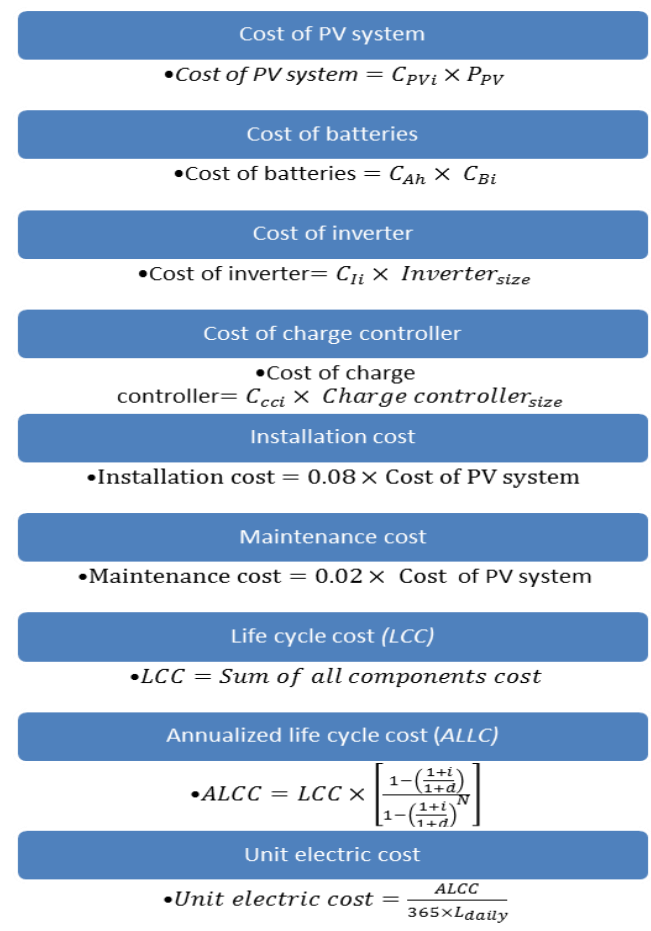

Fig. 11. Process and description of relationships used for life cycle cost analysis.

As, the designed size of system components varies significantly with peak sunshine hours that is why it is important to determine the sensitivity of associated costs as well. The variations of total life cycle cost, annualized life cycle cost, and unit electrical cost with respect to peak sunshine hours are presented in Fig. 12, 13, and 14, respectively. The total life cycle cost drops from 80,7000

to 62,1000 PKR with the increase in peak sunshine hour from 5 to 6.5 as it can be observed from Fig. 12. Whereas, the annualized life cycle cost decreases from 91,690 to 79,181 PKR/year corresponding to the peak sunshine hours of 5 and 6.5 (Fig. 13). The estimated unit electrical cost corresponding to peak sunshine hours of 5, 5.5, 6, and 6.5 is found to be $8.94,8.46,8.06$, and $7.72 \mathrm{PKR} / \mathrm{kWh}$, respectively as it can be observed from Fig. 14. From sensitivity analysis, it can be observed that solar intensity have a significant effect on overall system cost.

The current unit cost of conventional electric supply in Pakistan ranges from $15-20 \mathrm{PKR} / \mathrm{kWh}$ which means that produced electricity from installed off-grid PV system is 50 to $55 \%$ cheaper as compared to conventional grid supplied electricity. The initial cost of PV modules is decreasing with time. This will cause a decrease in cost of power generation from solar PV technology. Furthermore, the subsidies and support provided by the government of Pakistan will further decrease the unit cost of electricity from the PV system.

Apart from cheaper electricity, the installed power plant also has environmental benefits. The development and implementation of off grid PV power plants for household electrification will lower the dependence on imported fossil fuels for electrification in Pakistan and other developing countries. The integration of solar based electrification technology in the Country will help to achieve a sustainable energy mix in the Country as this will help to overcome increasing emission of greenhouse gases.

Table IV: Unit costs of components and other associated factors for financial analysis.

\begin{tabular}{|l|c|c|}
\hline Item & Value of one unit & Source \\
\hline PV module & $100 \mathrm{PKR} / \mathrm{W}$ & {$[10]$} \\
\hline Battery & $105 \mathrm{PKR} / \mathrm{Ah}$ & {$[11]$} \\
\hline Charge controller & $50 \mathrm{PKR} / \mathrm{A}$ & {$[10]$} \\
\hline Inverter & $20 \mathrm{PKR} / \mathrm{W}$ & {$[12]$} \\
\hline
\end{tabular}

Table V: Obtained results for life cost analysis.

\begin{tabular}{|l|c|c|}
\hline Item & Value in PKR & Value in Euro (€) \\
\hline Cost of PV system & 577,000 PKR & $4439 €$ \\
\hline $\begin{array}{l}\text { Cost of initial set of } \\
\text { batteries }\end{array}$ & 180,600 PKR & $1389 €$ \\
\hline $\begin{array}{l}\text { Cost of batteries after 5 } \\
\text { years }\end{array}$ & 164,752 PKR & $1267 €$ \\
\hline Cost of batteries after & 150,296 PKR & $1156 €$ \\
\hline
\end{tabular}


INTERNATIONAL JOURNAL OF SMART GRID

M.M Rafique., Vol. 2, No. 2, 2018

\begin{tabular}{|l|c|c|}
\hline 10 years & 137,108 PKR & $1055 €$ \\
\hline $\begin{array}{l}\text { Cost of batteries after } \\
15 \text { years }\end{array}$ & 125,077 PKR & $962 €$ \\
\hline $\begin{array}{l}\text { Cost of batteries after } \\
20 \text { years }\end{array}$ & 12,020 PKR & $93.8 €$ \\
\hline $\begin{array}{l}\text { Cost of charge } \\
\text { controller }\end{array}$ & $128,200 \mathrm{PKR}$ & $986 €$ \\
\hline Cost of Inverter & $11,540 \mathrm{PKR}$ & $89.7 €$ \\
\hline Cost of maintenance & $46,160 \mathrm{PKR}$ & $355 €$ \\
\hline Cost of installation & $11,540 \mathrm{PKR}$ & $89.6 €$ \\
\hline Miscellaneous costs & $1,544,293 \mathrm{PKR}$ & $11,879 €$ \\
\hline $\begin{array}{l}\text { Total life cycle cost } \\
\text { (LCC) }\end{array}$ & $76,332 \mathrm{PKR} / \mathrm{year}$ & $587 € / \mathrm{year}$ \\
\hline $\begin{array}{l}\text { Annualized LCC } \\
(A L C C)\end{array}$ & $7.44 \mathrm{PKR} / \mathrm{kWh}$ & $0.057 € / \mathrm{kWh}$ \\
\hline Unit electrical cost
\end{tabular}

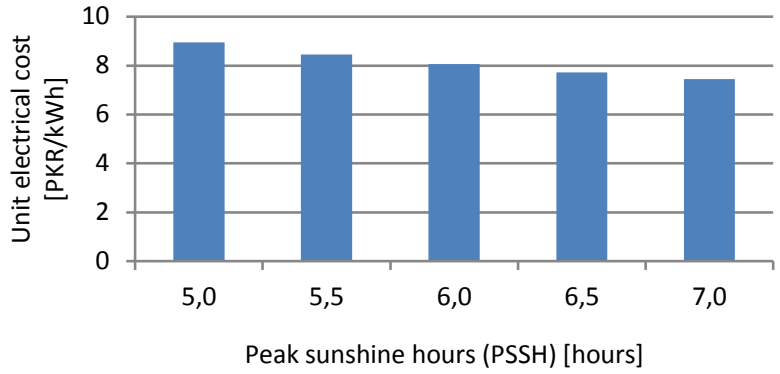

Fig. 14. Unit electric cost for different peak sunshine hours.

\section{Conclusions}

The implementation of renewable based technologies for household electrification is a need of the day in developing countries like Pakistan. In this paper, a simplified design procedure is presented to size an off grid PV system to fulfill the load demands of a household. The life cycle cost analysis of the PV system for single household application has also been estimated based on the market available prices in the Country and inflation rate. The obtained results from the present study indicate that development and implementation of off grid PV system to fulfill load demands of a household is beneficial and suitable for long-term investments. The achieved electricity rate from off grid PV system is found to be 50 to 55\% cheaper as compared to conventional electricity supplied in Pakistan. Apart from that, the prices associated with solar technology are decreasing which will further reduce the associated costs for development of solar assisted power plants. Also, the efficiency of the solar cells is increasing day by day which will make it further economical. That is why; solar PV power plants are most promising energy source for climatic conditions of Pakistan and would be the better option for household electrification in the Country.

From the obtained value of unit electric cost of the installed system and comparing it with the current electricity rate in other countries, it can be easily assessed whether the project is financially viable. These modelled equations can be used to assess the feasibility of a power system across different countries using site specific data.

\section{References}

[1] M.M. Rafique, M.A. Shakir, G.Y. Chohan. Statistical and econometric estimation of current and projected energy utilization in Pakistan. NFC IEFR Journal of Engineering and Scientific Research, 5 (2018).

Fig. 13. Annualized life cycle cost for different peak sunshine hours

[2] M.M. Rafique, S. Rehman. National energy scenario of Pakistan-Current status, future alternatives, and institutional infrastructure: An overview. Renewable and Sustainable Energy Reviews, 69 (2017) 156-167.

[3] M.M. Rafique, S. Rehman, Luai M. Alhems. Developing zero energy and sustainable villages - A 
case study for communities of the future, Renewable Energy, 127 (2018) 565-574.

[4] N. Abas, A. Kalair, N. Khan, A.R. Klair. Review of GHG emissions in Pakistan compared to SAARC countries, 80 (2017) 990-1016.

[5] OECD, Technology roadmaps concentrating solar power, Int. Energy Agency, (OECD/IEA), 2010.

[6] NREL, National renewable energy laboratory, 2013 (http://www.nrel.gov/) [Retrieved on October 10, 2017].

[7] S. Khan, M. Ul-Hasan, M.A. Khan. Annual and seasonal distribution of sunshine in Pakistan 19311990. In Water resources and wetlands, Conference Proceedings (2012) (pp. 14-16).

[8] M.T. Chaichan, H.A. Kazem. Generating Electricity Using Photovoltaic Solar Plants in Iraq. Springer; 2018 Apr 24.

[9] O.C. Okoye, O. Taylan, D.K. Baker . Solar energy potentials in strategically located cities in Nigeria: review, resource assessment and PV system design. Renew Sustain Energy Rev 55 (2016): 550-566.

[10] https://www.freecleansolar.com/180W-moduleSuntech-STP180S-24-Ad-plus-mono-p/stp180s-24ad-plus.htm [Retrieved on 11 May 2018]

[11] http://pakmotors.pk/ags-batteries-price-in-pakistan/ [Retrieved on 11 May 2018]

[12] http://www.pricenow.com.pk/index.php/powerprodu cts/inverters/inverex [Retrieved on 11 May 2018] 